\title{
СОСТОЯНИЕ ПРЕСТУПНОСТИ ПРОТИВ ЖИЗНИ И ЗАОРОВЬЯ И ПРОТИВ СОБСТВЕННОСТИ В УКРАИНЕ
}

\author{
С.К. Гречанюк ${ }^{1}$, П.П. Сердюк ${ }^{2}$ \\ ${ }^{1}$ Город Тернополь, Украина \\ ${ }^{2}$ Национальная академия прокуратуры Украины, г. Киев, Украина
}

\section{Информация о статье}

Дата поступления

16 мая 2017 г.

Дата принятия в печать 16 февраля 2018 г.

Дата онлайн-размещения 2 марта 2018 г.

\section{Ключевые слова}

Мониторинг; медиана; мода; математически ожидаемое число преступлений; преступность; преступления против жизни и здоровья; преступления против собственности; состояние преступности
Аннотация. Авторы предлагают к рассмотрению вопрос состояния преступности против жизни и здоровья и против собственности в Украине. В статье отмечается, что мониторинг состояния преступности является текущей исследовательской деятельностью, которая, по сути, представляет собой сбор эмпирического материала. Сбор эмпирического материала и его первичное обобщение, предварительные оценки составляют часть исследовательской работы и не могут претендовать на окончательный научный продукт. В публикации авторы преследуют цель не только представить данные о состоянии преступности, посягающей на жизнь и здоровье и на собственность, но и обратить внимание на ряд вопросов, которые имеют научное значение. В частности, в статье отмечены параметры соотношения количества зарегистрированных преступлений и количества выявленных лиц, совершивших эти преступления. Раскрыта возрастная структура лиц, которые совершили преступления, посягающие на жизнь и здоровье и на собственность. Представлены параметры, касающиеся потерпевших от этих видов преступлений, говорящие о том, что наиболее уязвимой группой населения являются не женщины и дети, а мужчины. Показаны медиана, мода и математически ожидаемое число преступлений этих видов в Украине за 2016 г. Отмечено, что из-за самого подхода, который задается характером ведения Единого реестра досудебных расследований и соответствующего ему статистического сопровождения, затруднено вычисление динамики сезонных колебаний в целом по стране и на уровне регионов Украины. Для вычисления сезонных колебаний преступности необходимо использовать особую технику. Но этот подход будет содержать ошибки в квалификации и не исключать возможность того, что в декабре внесенные изменения будут свидетельствовать о том, что в мае количество зарегистрированных преступлений было меньше, чем это было зафиксировано хронологически. Сделаны выводы относительно корреляции между количеством народонаселения в регионах Украины и количеством зарегистрированных преступлений этих видов.

\section{THE STATE OF CRIME AGAINST LIFE AND HEALTH AND AGAINST PROPERTY IN UKRAINE}

\author{
Sergey K. Hrechaniuk ${ }^{1}$, Pavel P. Serdiuk ${ }^{2}$ \\ ${ }^{1}$ Ternopol, Ukraine \\ ${ }^{2}$ National Academy of Prosecutor's Office of Ukraine, Kiev, Ukraine
}

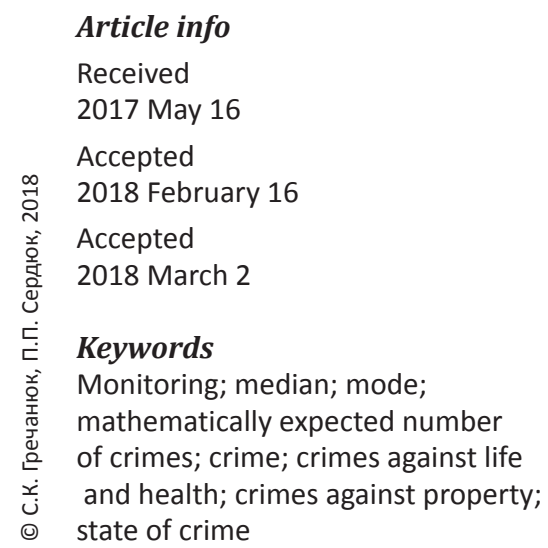

\begin{abstract}
The authors examine the state of crime against life and health and against property in Ukraine. The monitoring of criminal situation is an ongoing research activity that consists, in effect, of collecting empirical data. Collecting empirical evidence, its primary analysis and preliminary assessment are part of research work and cannot be viewed as the final research result. The goal of the authors of this paper is not only to present some data on the crimes infringing upon life, health and property, but also to draw attention to a number of issues significant for research. Thus, the paper presents the correlation between the number of registered crimes and the number of identified persons who committed these crimes. It describes the age structure of persons guilty of crimes against life and health and against property. It also offers information about the victims of such crimes, according to which the most vulnerable group of people is not women and children, but men. The authors present the median, the mode and the mathematically expected number of such crimes in Ukraine in 2016. They note that the approach resulting from the procedure of maintaining the Unified Register of Pre-trial Investigation and the accompanying statistical work make it difficult to calculate the dynamics of seasonal fluctuations in the country as a whole as well as in the regions of
\end{abstract}


Ukraine. A special technique should be used to calculate seasonal fluctuations of crime. However, this approach will lead to errors in qualification and will not eliminate the possibility that changes introduced in December will show that the number of crimes registered in May was smaller than the number of chronologically registered crimes. The authors make some conclusions regarding the correlation between the number of residents in different regions of Ukraine and the number of registered crimes of this type.

Идея освещать в научных публикациях вопрос, касающийся текущего состояния преступности в какой-либо географической локации, может вызывать вполне обоснованные сомнения. Дело в том, что описание ситуации может относиться к научному методу, но дает ли это приращение знаний? Очевидно, что да. Но в таком случае публикации статистических отчетов о состоянии преступности тоже являются научными публикациями. В таком случае, если их поместить в научном журнале, то такая публикация будет соответствовать критериям научной публикации. Последнее утверждение у многих вызовет некоторые сомнения. Правоохранительные органы публикуют такие результаты, не претендуя на научность характера этих публикаций. А как быть, если в таком статистическом отчете будет представлено обобщение данных? Например, элементарные выводы о динамике могут претендовать на такое обобщение. Но, строго говоря, поскольку эту техническую работу может проделать даже средний студент, любой аналитик правоохранительного органа, то вряд ли эту публикацию можно считать научной. Представляется, что здесь нужны повышенные требования к факту приращения знаний. Это должно превращаться в изложение фактов, которые могут быть доступны всем, кто пожелает.

Разумеется, можно снабдить изложение и обобщение статистических данных за сколь угодно продолжительный период - один, три, шесть, десять, сто лет - комментариями относительно динамики, ухудшения или, напротив, улучшения чего-либо [1]. На наш взгляд, такое изложение вряд ли имеет научный характер. А вот если исследователь раздобыл давно потерянные данные или сам добыл эмпирический материал, произведя самостоятельные исследования, которые либо подтверждают, либо опровергают выраженные в официальной статистике данные, то тут, пожалуй, можно задуматься о действительном приращении новых знаний.

На наш взгляд, мониторинг состояния преступности является текущей исследовательской деятельностью, которая, по сути, представляет собой сбор эмпирического материала. Что-то на- подобие мониторинга погоды. Но вряд ли можно считать, что публикация этого мониторинга носит характер научной. Сбор эмпирического материала и его первичное обобщение и даже предварительные оценки составляют часть исследовательской работы, но вряд ли это может претендовать на окончательный научный продукт, коей является научная статья или монография.

Есть научные публикации, которые посвящены вопросу мониторинга состояния преступности как некой методики сбора и оценки данных, сложностям и возможностям, раскрывающимся в мониторинге. Таким образом, мониторинг и демонстрация состояния преступности как часть этого мониторинга представляет собой метауровень вопроса, когда оцениваются сами методы накопления научно значимой информации. Это уже другой вопрос [2, с. 98-99, 100; 3, с. 101; 4; 5]. Мысль о проведении мониторинговых исследований вращается вокруг цели создания системы производства и накопления статистики об изменениях объема, уровня, структуры отклоняющегося поведения и эффективности социального контроля этого поведения [6, с. 16; 7, с. 8].

Совсем другое дело, когда собранный материал подвергается критическому исследованию, устанавливаются корреляции, находятся противоречия и закономерности. Исследователь может избрать любой период, за который он желает оценить параметры преступности в определенной географической или административно-территориальной локации. При этом важно, чтобы оно не ограничилось общими оценками о динамике и о возможном ухудшении условий жизни населения и работы правоохранительных органов. Либо же в редких случаях об улучшении оных.

Нам не удалось найти научные публикации в странах Западной Европы, США, Канаде, Австралии, которые бы были посвящены исключительно обзору состояния преступности в стране и (или) регионе. Напротив, существующие публикации связывают состояние преступности с сопутствующими проблемами. Это и вопрос о том, естественно ли состояние преступности в ряде государств, и вопрос сезонных колебаний видов преступности, и влияние ряда факторов 
на состояние преступности в избранные периоды в отобранных регионах, и многие другие вопросы [8-10]. Хотя можно с большой вероятностью ожидать, что они существуют. Имеются в виду те, которые предлагают в чистом виде описание состояния преступности с некоторыми обобщениями и оценками [11-19]. Изобилие подобных публикаций наблюдается среди криминологов Восточной Европы.

Мы же имеем своей целью не только представить данные о состоянии преступности, посягающей на жизнь и здоровье и на собственность, но и обратить внимание на ряд вопросов, которые имеют научное значение. Нужно отметить, что в советской криминологии сложилась классификация преступности на виды более широкого охвата, чем по разделам Уголовного кодекса. Однако вполне очевидно, что насильственная, корыстно-насильственная и экономическая преступность включает куда более широкий горизонт. Как ни печально отмечать, но фактически можно заключить, что, действуя в угоду этой классификации, мы не сможем увидеть корреляций между колебаниями одних и других разновидностей насильственных преступлений, чьи подвиды весьма обширны. С другой стороны, не хочется подыгрывать диктату уголовного права в криминологии, проявления которого можно наблюдать и сегодня. Всё же даже взятые произвольно виды преступлений представляют научный интерес и могут нам говорить о разнообразных проявлениях, важных для приращения новых знаний.

Количество учтенных преступлений против жизни и здоровья человека в Украине за 2016 г. составило 45 979, а преступлений против собственности - 405 549. Но выявленных лиц, совершивших преступления против жизни и здоровья человека, в целом по стране за 2016 г. насчитывалось 17 068, а тех, кто совершил преступления против собственности, - 52 031. Что касается данных на региональном уровне, то количество выявленных лиц, совершивших преступления, представлено лишь в общем виде, без дифференциации на виды преступлений. Очевидная разница между этими позициями чаще всего преподносится как низкая эффективность расследования преступлений, как будто других вариантов и не может быть.

Мейнстрим этого вопроса не может допустить, что уровень латентности преступлений может снижаться, посему не принято открыто предполагать, что разница между учтенными преступлениями и количеством выявленных лиц, совершивших такие преступления, может быть за счет иного. Что часть зарегистрированных преступлений по заявлениям может быть завышенной, поскольку общее количество таких учтенных преступлений пребывает в пределах математически ожидаемого количества деликтов с учетом дисперсии. Поскольку, как считается, преступления против жизни и здоровья, если быть точным, то убийства и тяжкие телесные повреждения, наименее латентны, то и разница между учтенными преступлениями и выявленными лицами, их совершившими, не такая большая, как для преступлений против собственности. Если сравнить, то соотношение между количеством зарегистрированных преступлений против жизни и здоровья и количеством выявленных лиц, их совершивших, составляет 2,7 : 1. Для преступлений против собственности это соотношение составляет 7,8 : 1. И это не латентные преступления. В криминологии есть важный вопрос, нуждающийся в прояснении. Какая часть учтенных преступлений относится к так называемой гиперрегистрации, т.е. той, которая осуществлена со слов потерпевших, но в действительности факт не подтверждается и это не является результатом невозможности расследовать преступление и найти преступника. Всё же это преступление остается в реестре. На этот вопрос не обращают внимания, поскольку он считается неактуальным из-за того, что всех волнует латентная преступность. Посему не допускают, что можно посягнуть на учтенную преступность. Мысль не восходит к тому, чтобы допустить возможность, что регистрация может быть завышенной. Эта проблема обострена тем, что социологические опросы говорят о запредельной преступности и виктимизации, поэтому многих волнует не то, что в реестрах что-то преувеличено, а то, что в реестр не попадает то, что декларируется в самоотчетах и указаниях на виктимизацию в ответах респондентов социологических опросов.

Выделенные в статистическом отчете данные о лицах, совершивших преступления, позволяют определить пропорции количества лиц мужского и женского пола среди выявленных лиц, совершивших преступления против жизни и здоровья человека. Среди всех выявленных лиц, совершивших преступления, за 2016 г. мужчины составляют 88,2 \%, а женщины - 11,8 \%. Согласно этим данным, можно определить долю лиц, совершивших преступления против жизни и здоровья человека, по половому признаку. Так, среди лиц, совершивших преступления против 
жизни и здоровья, мужчины составляют 89,5 \%, соответственно, женщины - 10,5\%. Среди лиц, совершивших преступления против собственности, мужчины составляют 88,4 \%, женщины $11,6 \%$. По всему видно, что такое распределение соответствует общей пропорции.

Указанные данные не выделяются по половому признаку в регионах страны. Это затрудняет возможность определения различий не только по видам преступлений, но и по регионам, что не оставляет возможности выявления корреляций.

Очевидно, что наиболее криминально активной группой лиц по возрасту являются лица в возрасте от 18 до 28 лет, т.е. представители так называемой молодежной преступности. Однако возрастная группа от 29 до 54 лет также дает значительную долю в удельном весе указанных преступлений.

Возрастная группа от 0 до 14 лет должна быть уменьшена до группы от 11 до 14 лет, поскольку количество лиц от 0 до 11 лет будет создавать количественный фон и искажать сравнения. Поэтому был смысл начинать расчет по возрастной группе от 11 лет, поскольку именно с такого возраста могут возникать уголовно-правовые отношения (табл. 1, 2).

\section{Ранжир выявленных лиц, которые совершили преступления против жизни и здоровья (по возрастному признаку в рамках возрастных когорт)}

The rankings of individuals who have committed crimes against life and health

(based on age within the age cohorts)

\begin{tabular}{|c|c|c|c|c|c|c|c|c|}
\hline $\begin{array}{c}\text { Вид престу- } \\
\text { плений / } \\
\text { Kind of crimes }\end{array}$ & $\begin{array}{c}\text { До } \\
14 \text { лет / } \\
\text { Under } \\
14 \text { years } \\
\text { old }\end{array}$ & $\begin{array}{c}\text { 14-15 лет / } \\
\text { Between } 14 \\
\text { and } 15 \text { years } \\
\text { old }\end{array}$ & $\begin{array}{c}\text { 16-17 лет / } \\
\text { Between } 16 \\
\text { and } 17 \text { years } \\
\text { old }\end{array}$ & $\begin{array}{c}\text { 18-28 лет / } \\
\text { Between } 18 \\
\text { and } 28 \text { years } \\
\text { old }\end{array}$ & $\begin{array}{c}\text { 29-39 лет / } \\
\text { Between } 29 \\
\text { and } 39 \text { years } \\
\text { old }\end{array}$ & $\begin{array}{l}\text { 40-54 лет / } \\
\text { Between } 40 \\
\text { and } 54 \text { years } \\
\text { old }\end{array}$ & $\begin{array}{c}55-59 \text { лет / } \\
\text { Between } 55 \\
\text { and } 59 \text { years } \\
\text { old }\end{array}$ & $\begin{array}{c}60 \text { лет } \\
\text { и старше / } \\
60 \text { years old } \\
\text { and older }\end{array}$ \\
\hline $\begin{array}{l}\text { Преступле- } \\
\text { ния против } \\
\text { жизни } \\
\text { и здоровья / } \\
\text { Crimes against } \\
\text { life and health }\end{array}$ & 27 & 66 & 380 & 4836 & 5732 & 4405 & 776 & 846 \\
\hline $\begin{array}{l}\text { Удельный } \\
\text { вес, \% / } \\
\text { Specific } \\
\text { weight, \% }\end{array}$ & 0,2 & 0,4 & 2,2 & 28,3 & 33,6 & 25,8 & 4,6 & 5,0 \\
\hline
\end{tabular}

Источник: Статистична інформація про стан злочинності та результати прокурорсько-слідчої діяльності / Генеральна прокуратура України. URL: http://www.gp.gov.ua/ua/stst2011.html?dir_id=112661\&libid=100820\&c=edit\&_c=fo.

Ранжир выявленных лиц, которые совершили преступления против собственности

Таблица 2 / Table 2 (по возрастному признаку в рамках возрастных когорт)

The rankings of individuals who have committed crimes against property

(based on age within the age cohorts)

\begin{tabular}{|c|c|c|c|c|c|c|c|c|}
\hline $\begin{array}{c}\text { Вид } \\
\text { преступлений / } \\
\text { Kind of crimes }\end{array}$ & $\begin{array}{c}\text { До } 14 \text { лет / } \\
\text { under } \\
14 \text { years } \\
\text { old }\end{array}$ & $\begin{array}{c}\text { 14-15 лет / } \\
\text { Between } 14 \\
\text { and } 15 \text { years } \\
\text { old }\end{array}$ & $\begin{array}{c}\text { 16-17 лет / } \\
\text { Between } 16 \\
\text { and } 17 \text { years } \\
\text { old }\end{array}$ & $\begin{array}{l}\text { 18-28 лет / } \\
\text { Between } 18 \\
\text { send } 28 \text { years } \\
\text { old }\end{array}$ & $\begin{array}{c}\text { 29-39 лет / } \\
\text { Between } 29 \\
\text { and } 39 \text { years } \\
\text { old }\end{array}$ & $\begin{array}{c}40-54 \text { лет / } \\
\text { Between } 40 \\
\text { and } 54 \text { years } \\
\text { old }\end{array}$ & $\mid \begin{array}{c}55-59 \text { лет / } \\
\text { Between } 55 \\
\text { and } 59 \text { years } \\
\text { old }\end{array}$ & $\begin{array}{c}60 \text { лет и } \\
\text { старше / } \\
60 \text { years } \\
\text { old and } \\
\text { older }\end{array}$ \\
\hline $\begin{array}{l}\text { Преступления } \\
\text { против собствен- } \\
\text { ности / Crimes } \\
\text { against property }\end{array}$ & 178 & 962 & 2084 & 18858 & 18623 & 9409 & 1194 & 723 \\
\hline $\begin{array}{l}\text { Удельный вес, } \\
\% \text { / Specific } \\
\text { weight, \% }\end{array}$ & 0,3 & 1,9 & 4,0 & 36,2 & 35,8 & 18,1 & 2,3 & 1,4 \\
\hline
\end{tabular}

Источник: Статистична інформація про стан злочинності та результати прокурорсько-слідчої діяльності / Генеральна прокуратура України. URL: http://www.gp.gov.ua/ua/stst2011.html?dir_id=112661\&libid=100820\&c=edit\&_c=fo. 
Судя по данным, утверждение о высокой криминальной активности молодежи в возрасте от 18 до 29 лет можно объяснить долей такого населения в его общей возрастной структуре. Из этой логики выбиваются две возрастные группы населения в возрасте от 11 до 14 лет и от 60 лет и старше. По первой надо пояснить, что бо́льшая часть детей этого возраста находится под родительским присмотром и формальным социальным контролем учреждений, и только у заброшенных с этой точки зрения несовершеннолетних больше вероятности совершить эти преступления. Совершенно ясно, что это предположение нужно подтверждать экспериментально, одного умозрительного видения недостаточно. А по второй группе, в возрасте от 60 лет и старше, она самая многочисленная, только лица в возрасте от 80 лет и старше составляют 1469377 чел., и эффект старения популяции очевиден. Вероятно, было бы продуктивным разделить возрастную когорту более дробно, чтобы увидеть, какая из возрастных групп пожилого и старческого населения имеет наивысшую криминальную активность. Предположительно, это должна быть группа, близкая к 60-летнему возрасту. Однако проблема в том, что в уголовной статистике Украины возрастная группа от 60 лет и старше не дифференцируется более дробно. Впрочем, невысокая доля таких лиц в совершенных преступлениях объясняется преклонным возрастом (табл. 3).
За 2016 г. был зарегистрирован 5681 потерпевший от преступлений против жизни и здоровья, что составило 1,3 \% от всех потерпевших от преступлений. Это ощутимо меньше, чем количество учтенных преступлений против жизни и здоровья, а также меньше, чем количество выявленных лиц, совершивших преступления против жизни и здоровья. Эту ситуацию можно объяснить тем, что в статистических отчетах отсутствуют данные о потерпевших от преступлений средней тяжести и легких телесных повреждений.

Что касается потерпевших от преступлений против собственности, то в 2016 г. их было зарегистрировано 344390 чел., т.е. 77,5 \% от всех зарегистрированных преступлений против собственности за отчетный период. Сложно объяснить эту ситуацию. Возможно, часть потерпевших не была обнаружена. Однако этот вопрос еще более обостряется, если вспомнить о том, что в части уголовных производств жертвами одного преступления признаются несколько человек, а также обратить внимание на то, что в другой части производств может быть один потерпевший от нескольких преступлений, если оно не продолжаемое. Возможно, в этой ситуации и надо искать ответ. Но искать, а не ограничиться только этим предположением. Для этого, правда, нужно будет пересмотреть все уголовные производства по таким преступлениям за 2016 г. В Украине это может сделать только пер-

\section{Удельный вес выявленных лиц, совершивших преступления (по возрастному признаку в рамках возрастных когорт)}

Таблица 3 / Table 3

The specific weight of individuals who have committed crimes (based on age within the age cohorts)

\begin{tabular}{|c|c|c|c|c|c|c|c|c|}
\hline $\begin{array}{c}\text { Вид преступлений / } \\
\text { Kind of crimes }\end{array}$ & $\begin{array}{c}\text { До } 14 \text { лет / } \\
\text { Under } \\
14 \text { years } \\
\text { old }\end{array}$ & $\begin{array}{c}14- \\
15 \text { лет / } \\
\text { Between } \\
14 \text { and } \\
15 \text { years } \\
\text { old }\end{array}$ & $\begin{array}{l}16- \\
17 \text { лет / } \\
\text { Between } \\
16 \text { and } \\
17 \text { years } \\
\text { old }\end{array}$ & $\begin{array}{c}18- \\
28 \text { лет / } \\
\text { Between } \\
18 \text { and } \\
28 \text { years } \\
\text { old }\end{array}$ & $\begin{array}{l}29- \\
39 \text { лет / } \\
\text { Between } \\
29 \text { and } \\
39 \text { years } \\
\text { old }\end{array}$ & $\begin{array}{l}40- \\
54 \text { лет / } \\
\text { Between } \\
40 \text { and } \\
54 \text { years } \\
\text { old }\end{array}$ & $\begin{array}{c}55- \\
59 \text { лет / } \\
\text { Between } \\
55 \text { and } \\
59 \text { years } \\
\quad \text { old }\end{array}$ & $\begin{array}{c}60 \text { лет } \\
\text { и старше / } \\
60 \text { years old } \\
\text { and older }\end{array}$ \\
\hline $\begin{array}{l}\text { Удельный вес в совер- } \\
\text { шении преступлений } \\
\text { против собственности, } \\
\% \text { / Specific weight } \\
\text { in committing crimes } \\
\text { against property, \% }\end{array}$ & 0,3 & 1,9 & 4,0 & 36,2 & 35,8 & 18,1 & 2,3 & 1,4 \\
\hline $\begin{array}{l}\text { Удельный вес возраст- } \\
\text { ной группы в общем } \\
\text { населении, \% / Specific } \\
\text { weight of age group } \\
\text { in general population, \% }\end{array}$ & 3,5 & 1,7 & 1,8 & 14,3 & 17,5 & 13,7 & 7,3 & 22,1 \\
\hline
\end{tabular}

Источники: Розподілпостійного населення України за статтю та віком на 1 січня 2016 року / Відповідальна за випуск М.Б. Тімоніна. Київ : Державна служба статистики України, 2016. С. 8-9 ; Статистична інформація про стан злочинності та результати прокурорсько-слідчої діяльності / Генеральна прокуратура України. URL: http://www. gp.gov.ua/ua/stst2011.html?dir_id=112661\&libid=100820\&c=edit\&_c=fo. 
сона с соответствующим цифровым доступом. Это может быть следователь, прокурор или аналитик с электронным ключом доступа к Единому реестру досудебных расследований (ЕРДР).

Лиц женского пола, потерпевших от умышленных убийств и тяжких телесных повреждений, было 24,1 \%, а несовершеннолетних, включая детей, 2,8 \%, т.е. большинство потерпевших от умышленных убийств и тяжких телесных повреждений - лица мужского пола. Следовательно, можно сделать вывод, что женщины и дети не представляют собой наиболее уязвимую часть населения. От преступлений преимущественно страдают мужчины, притом что большинство преступников также являются мужчинами. Лица женского пола составляют 39,6 \% от всех потерпевших от преступлений против собственности, соответственно, лица мужского пола составляют 60,4 \%. А несовершеннолетние, включая детей до 14 лет, составляют 0,9 потерпевшего от этих преступлений.

Введение системы ЕРДР существенно осложнило возможность определить показатели сезонных колебаний преступности. Это можно увидеть на примере колебания регистрации преступлений против жизни и здоровья за 2016 г. Самый высокий показатель регистрации приходится на январь. Характер ведения ЕРДР уже не может отразить особенности регистрации преступлений по месяцам, поскольку речь идет об изменении квалификации деяния, а не самого факта преступления. Это объясняет то, что вполне возможны ситуации, когда в ноябре абсолютное количество учтенных преступлений против жизни и здоровья за весь период, с января по ноябрь, меньше, чем было в октябре. Этот феномен даже назвали «плавающей преступностью». Но это издержки правил ведения статистики по ЕРДР, которая динамична, в нее постоянно вносятся изменения, и в результате изменения в предварительной квалификации могут менять ситуацию с цифрами.

Из-за самого подхода, который задается характером ведения ЕРДР, и соответствующего ему статистического сопровождения не видно потребности, основываясь на этих данных, показывать динамику сезонных колебаний на уровне регионов Украины. Очевидно, что сейчас, чтобы оценивать эти колебания, надо прибегать к особой технике. Для этого надо знать количество зарегистрированных преступлений ежемесячно без учета последующей динамики переквалификации, для чего эти данные долж- ны фиксироваться без дальнейшего изменения. Такой подход будет содержать ошибки в квалификации, но, по крайней мере, он будет устранять возможность того, что в декабре внесенные изменения будут свидетельствовать о том, что в мае количество зарегистрированных преступлений было меньше, чем это было зафиксировано хронологически.

Для преступлений против собственности можно заметить тренд к уменьшению количества учтенных преступлений против собственности с начала года до его конца. В январе 2017 г. количество учтенных преступлений против собственности снова уменьшилось.

В структуре учтенных преступлений против жизни и здоровья наиболее количественно представлены умышленное убийство, умышленное тяжкое телесное повреждение, умышленное средней тяжести телесное повреждение, умышленное легкое телесное повреждение, побои и истязания, неосторожное тяжкое или средней тяжести телесное повреждение, угроза убийством, ненадлежащее исполнение профессиональных обязанностей медицинским или фармацевтическим работником.

Наиболее распространенным является умышленное легкое телесное повреждение. Причем это преступление относится к преступлениям частного обвинения. Со всей очевидностью данное правонарушение надо вывести за пределы уголовной юстиции, поскольку это распыляет мощности органов уголовной юстиции, по сути, на деяние, которое подчинено принципу диспозитивности. Региональные показатели отражают общую структурированность преступлений против жизни и здоровья по стране.

В структуре учтенных преступлений против собственности наиболее количественно представлены кража, грабеж, мошенничество, присвоение, растрата имущества или завладение им путем злоупотребления служебным положением.

Медиана преступлений против жизни и здоровья по стране за период с 2012 по 2016 г. составляет 51547 преступлений, т.е. показатель 2015 г. Медиана преступлений против собственности по стране за этот период составляет 322 345, т.е. также показатель за 2015 г. Это означает, что за этот период 2016 г. демонстрирует самый низкий показатель преступлений против жизни и здоровья, который меньше среднего показателя. Таким образом, колебание уровня преступности в стране неоднородно, зависит от вида преступлений. Впрочем, меди- 
ана количества населения, способного к деликту, в стране за указанный период составляет 38535200 чел., т.е. показатель 2014 г., что близко к показателю 2015 г., т.е. того года, который демонстрирует медиану преступлений против жизни и здоровья. В Украине население уменьшилось с 2014 г. больше чем на два миллиона. Это должно было, по крайней мере, уменьшить динамику роста преступлений. Но это не сказалось на преступлениях против жизни и здоровья. А население, как коррелят, должно влиять на такие показатели одинаково. Это может означать и то, что рост цен способствовал тому, что рыночная стоимость предмета преступлений против собственности возросла, а потому они чаще стали подпадать под критерий преступной кражи.

Определить моду учтенных преступлений за этот период не удалось, поскольку мода это значение, которое чаще всего встречается в данных, т.е. объект с наибольшей частотой. Но показатели учтенных преступлений против жизни и здоровья за этот период не имели достаточно близких цифр для определения моды. Это говорит о том, что осцилляции преступлений и учет этих осцилляций - естественное явление для преступности и больше соответствует критериям вероятности, нежели точности.

Преступления против собственности в Украине традиционно относятся к общеуголовной преступности, а кража дает наибольший количественный показатель для преступности. В этом плане колебания по сравнению с предыдущими периодами не дают места для тревоги, ведь в процентном виде преступления против собственности по состоянию на начало 2017 г. составляют лишь 1,09 \% к экономически активному населению. Поскольку официальной количественной нормы преступности, превышение которой дало бы повод для волнений, нет, можно утверждать, что пока такой показатель не превысит 5 \%, тревога преждевременна, а система находится в равномерном состоянии.

Численность населения деликтоспособного возраста и количество учтенных преступлений против жизни и здоровья, а также преступлений против собственности в регионах страны коррелируют. Измерения позволяют предполагать, что увеличение количества учтенных преступлений против собственности в регионах имеет экономическую природу и не свидетельствует о существенном увеличении делинквентности населения. Существующие погрешности говорят о том, что уровень латентности указанных преступлений различается по регионам страны, поскольку население является надежным средством для установления возможной погрешности в количестве учтенных преступлений [20, с. 50-130].

Математически ожидаемое количество преступлений против жизни и здоровья человека в целом по стране составило 752 970, а фактически учтено 45 979, что намного меньше. Математически ожидаемое количество преступлений против собственности в целом по стране составило 760 461, а фактически учтено 405 549. Таким образом, количество учтенных преступлений говорит о довольно низком уровне преступности данных видов. Можно предполагать, что это является результатом повышения уровня латентности этих преступлений. Не исключено. Однако современная криминология не может предложить удовлетворительных способов выявления уровня латентности преступлений. Упование же на виктимологические опросы не выдерживает критики [там же], и регистрация преступлений хотя и не точна, но всё же выполняет функцию выборки.

Учитывая вышеизложенное, необходимо заключить, что данные говорят о снижении уровня этих преступлений в Украине. Причем мы вынуждены отметить, что причин такого уменьшения, которые бы основывались на эмпирически выверенных научных доказательствах, нет. Предположения о занижении регистрации преступлений, а почему-то не о завышении, являются умозрительными, а посему не составляют научной ценности.

Важно отметить, что криминология по сей день не дала нам возможности оперировать категорией «нормы преступности», позволяющей давать оценки ситуации с преступностью, приклеивать ей знак высокой, средней или низкой. Существует очень важная потребность в изучении вопроса о норме преступности, которая бы учитывала динамичность процессов общественной жизни, и на базе этого весьма необходима методика определения такой нормы.

\section{СПИСОК ИСПОЛЬЗОВАННОЙ ЛИТЕРАТУРЫ}

1. Бесчастний В. Кримінологічний аналіз станузлочинності в Україні / В. Бесчастний // Підприємництво, господарство і право. - 2017. - № 1. - С. 207-213.

2. Блажівський Є.М. Моніторинг протидіїзлочинності / Є.М. Блажівський // Право та державне управління. - 2013. № 1. - С. 98-101. 
3. Блажівський Є.М. Кримінологічна характеристика методик моніторингу протидіїзлочинності / Є.М. Блажівський // Право і суспільство. - 2013. - № 1. - С. 97-101.

4. Monitoring the Crime Situation: a Developing Country Perspective / E. Carranza [et al.] // Forum on Crime \& Society. 2006. - Vol. 5, № 1. - P. 111-116.

5. Kalidien S. Towards a Tool for Monitoring Crime and Law Enforcement / S. Kalidien, S. Choenni, R. Meijer // Proceedings of the European Conference on Information Management \& Evaluation. - 2009. - № 1. - P. 239-247.

6. Брылев В.И. Методические вопросы мониторинга наркоситуации на региональном уровне / В.И. Брылев, И.В. Исупова // Вестник Краснодарского университета МВД России. - 2016. - № 3. - С. 14-18.

7. Стороженко И.В. Антикоррупционный мониторинг в криминологическом значении : автореф. дис. ... канд. юрид. наук : 12.00.08 / И.В. Стороженко ; Рос. правовая акад. М-ва юстиции РФ. - М., 2011. - 22 с.

8. Narayan P. Is There a Natural Rate of Crime? / P. Narayan, I. Nielsen, R. Smyth // The American Journal of Economics and Sociology. - 2010. - Vol. 69, № 2. - P. 759-782.

9. Yan Y. Seasonality of Property Crime in Hong Kong / Y. Yan // The British Journal of Criminology. — 2004. - Vol. 44, № 2. P. 276-283.

10. Schissel B. The Influence of Economic Factors and Social Control Policy on Crime Rate Changes in Canada, 1962-1988 / B. Schissel // The Canadian Journal of Sociology. - 1992. - Vol. 17, № 4. - P. 405-428.

11. Алиханов С.А. Анализ состояния и динамики преступности: по материалам Республики Дагестан / С.А. Алиханов // Следователь. - 2002. - № 1 (45). - С. 46.

12. Грень Р.Р. Сучасний стан злочинності в Україні у сфері обігу наркотичних засобів / Р.Р. Грень // Порівняльноаналітичне право. - 2016. - № 2. - С. 197-200.

13. Тимчук О.Л. Злочинність в Україні: сучасний стан, тенденції, детермінація / О.Л. Тимчук // Вісник ЗНУ. Юридичні науки. - 2012. - № 2, ч. 1. - С. 223-231.

14. Зозуля И.В. Состояние преступности в Украине (по материалам периодической печати) / И.В. Зозуля // Право і Безпека. - 2002. - № 1. - С. 55-63.

15. Іваненко Ю.Л. Стан злочинів, що вчинюються відносно осіб, які займаються бродяжництвом / Ю.Л. Іваненко // Держава та регіони. Серія: Право. - 2013. - № 1 (39). - С. 157-162.

16. Кальман О.Г. Злочинність в Україні: основні тенденції / О.Г. Кальман, І.О. Христич // Боротьба з організованою злочинністю і корупцією (теорія і практика). - 2007. - Вип. 17. - С. 41-56.

17. Головкін Б.М. Кримінологічна характеристика злочинності неповнолітніх у місті Харкові / Б.М. Головкін, В.С. Батиргареєва // Питання боротьби зі злочинністю : зб. наук. пр. - Харків, 2005. - Вип. 10. - С. 105-130.

18. Грудинин Н.С. Современное состояние и тенденции преступности в Москве / Н.С. Грудинин // Экономические, юридические и социокультурные аспекты развития регионов : сб. науч. тр. - Челябинск : ЧИЭП им. М.В. Ладошина, 2014. - С. 105-107.

19. Сухаренко А.Н. Криминальная ситуация на Дальнем Востоке в зеркале статистики / А.Н. Сухаренко // Ойкумена. Регионоведческие исследования. - 2013. - № 3. - С. 113-115.

20. Сердюк П.П. Относительное измерение интенсивности преступности / П.П. Сердюк. - Запорожье : Кругозор, 2016. $-1000 \mathrm{c}$.

\section{REFERENCES}

1. Beschastnii V. Kriminologichnii analiz stanuzlochinnosti v Ukraïni. Pidpriemnitstvo, gospodarstvo i pravo $=$ Entrepreneurship, Economy and Law, 2017, no. 1, pp. 207-213. (In Ukrainian).

2. Blazhivs'kii G.M. Monitoring protidiïzlochinnosti. Pravo ta derzhavne upravlinnya $=$ Law and Public Administration, 2013, no. 1, pp. 98-101. (In Ukrainian).

3. Blazhivs'kii Є.M. Kriminologichna kharakteristika metodik monitoringu protidiïzlochinnosti. Pravo $i$ suspil'stvo $=$ Law and Society, 2013, no. 1, pp. 97-101. (In Ukrainian).

4. Ciafardini M., Gastrow P., Guo J., Kahn T., Leones C., Sita M. Monitoring the Crime Situation: a Developing Country Perspective. Forum on Crime \& Society, 2006, vol. 5, no. 1, pp. 111-116.

5. Kalidien S., Choenni S., Meijer R. Towards a Tool for Monitoring Crime and Law Enforcement. Proceedings of the European Conference on Information Management \& Evaluation, 2009, no. 1, pp. 239-247.

6. Brylev V.I., Isupova I.V. Methodological aspects of monitoring the drug abuse situation at the regional level. Vestnik Krasnodarskogo universiteta MVD Rossii = Bulletin of Krasnodar University of the Ministry of Internal Affairs of Russia, 2016, no. 3, pp. 14-18. (In Russian).

7. Storozhenko I.V. Antikorruptsionnyi monitoring v kriminologicheskom znachenii. Avtoref. Kand. Diss. [Anticorruption monitoring in the criminological sense. Cand. Diss. Thesis]. Moscow, 2011. 22 p.

8. Narayan P., Nielsen I., Smyth R. Is There a Natural Rate of Crime? The American Journal of Economics and Sociology, 2010, vol. 69 , no. 2, pp. 759-782.

9. Yan Y. Seasonality of Property Crime in Hong Kong. The British Journal of Criminology, 2004, vol. 44, no. 2, pp. 276-283.

10. Schissel B. The Influence of Economic Factors and Social Control Policy on Crime Rate Changes in Canada, 1962-1988. The Canadian Journal of Sociology, 1992, vol. 17, no. 4, pp. 405-428.

11. Alikhanov S.A. The analysis of the condition and dynamics of crime: based on the materials from the Republic of Dagestan. Sledovatel' = Investigator, 2002, no. 1 (45), pp. 46. (In Russian).

12. Gren' R.R. Suchasnii stan zlochinnosti v Ukraïni u sferi obigu narkotichnikh zasobiv. Porivnyal'no-analitichne pravo = Comparative-Analytical Law, 2016, no. 2, pp. 197-200. (In Ukrainian).

13. Timchuk O.L. Zlochinnist' v Ukraïni: suchasnii stan, tendentsiï, determinatsiya. Visnik ZNU. Yuridichni nauki=Bulletin of Zaporizhzhya National University. Legal Sciences, 2012, no. 2, pt. 1, pp. 223-231. (In Ukrainian). 
14. Zozulya I.V. Sostoyanie prestupnosti v Ukraine (po materialam periodicheskoi pechati). Pravo $i$ Bezpeka= Law and Safety, 2002, no. 1, pp. 55-63. (In Ukrainian).

15. Ivanenko Yu.L. Stan zlochiniv, shcho vchinyuyut'sya vidnosno osib, yaki zaimayut'sya brodyazhnitstvom. Derzhava ta regioni. Seriya: Pravo = The State and the Regions. Series: Law, 2013, no. 1 (39), pp. 157-162. (In Ukrainian).

16. Kal'man O.G., Khristich I.O. Zlochinnist' v Ukraïni: osnovni tendentsiï. Borot'ba z organizovanoyu zlochinnistyu i koruptsieyu (teoriya i praktika) = Counteracting Organized Crime and Corruption (Theory and Practice), 2007, iss. 17, pp. 41-56. (In Ukrainian).

17. Golovkin B.M., Batirgare $\in$ va V.S. Kriminologichna kharakteristika zlochinnosti nepovnolitnikh u misti Kharkovi. Pitannya borot'bi zi zlochinnistyu. Kharkov, 2005, iss. 10, pp. 105-130. (In Ukrainian).

18. Grudinin N.S. The contemporary condition and trends of crime in Moscow. Ekonomicheskie, yuridicheskie i sotsiokul'turnye aspekty razvitiya regionov [Economic, Legal and Socio-Cultural Aspects of Regional Development]. M.V. Ladoshin Chelyabinsk Institute of Economics and Publ., 2014, pp. 105-107. (In Russian).

19. Sukharenko A.N. The criminal situation in the Far East in the mirror of statistics. Oikumena. Regionovedcheskie issledovaniya = Ecumene. Regional Studies, 2013, no. 3, pp. 113-115. (In Russian).

20. Serdyuk P.P. Otnositel'noe izmerenie intensivnosti prestupnosti [The Relative Measurement of Criminal Intensity]. Zaporozhye, Krugozor Publ., 2016. 1000 p.

\section{ИНФОРМАЦИЯ ОБ АВТОРАХ}

Гречанюк Сергей Константинович - доктор юридических наук, доцент, адвокат, г. Тернополь, Украина; e-mail: hrechserge@mail.ru.

Сердюк Павел Павлович - главный научный сотрудник Национальной академии прокуратуры Украины, доктор юридических наук, профессор, г. Киев, Украина.

\section{ДЛЯ ЦИТИРОВАНИЯ}

Гречанюк С.К. Состояние преступности против жизни и здоровья и против собственности в Украине / С.К. Гречанюк, П.П. Сердюк // Всероссийский криминологический журнал. - 2018. - Т. 12, № 1. - С. 23-31. - DOI: 10.17150/2500-4255.2018.12(1).23-31.

\section{INFORMATION ABOUT THE AUTHORS}

Hrechaniuk, Sergey K. - Doctor of Law, Ass. Professor, Lawyer, Ternopol, Ukraine; e-mail: hrechserge@mail.ru.

Serdiuk, Pavel P. - Senior Researcher, National Academy of Prosecutor's Office of Ukraine, Doctor of Law, Professor, Kiev, Ukraine.

\section{FOR CITATION}

Hrechaniuk S.K., Serdiuk P.P. The state of crime against life and health and against property in Ukraine. Vserossiiskii kriminologicheskii zhurnal = Russian Journal of Criminology, 2018, vol. 12, no. 1, pp. 23-31. DOI: 10.17150/25004255.2018.12(1).23-31. (In Russian). 